\title{
Data Mining Predictive Modeling for Prediction of Gold Prices Based on Dollar Exchange Rates, Bi Rates and World Crude Oil Prices
}

\author{
Iman Priyadi ${ }^{1}$, Julius Santony ${ }^{2}$, Jufriadif $\mathrm{Na}^{\prime} \mathbf{a m}^{3}$ \\ 1,2,3 Magister Ilmu Komputer, Universitas Putra Indonesia Padang \\ Email : 1iman.priyadi@merantikab.go.id, 2 juliussantony@yahoo.co.id, 3 jufriadif@yahoo.com
}

\author{
Article Info \\ Article history: \\ Received Mar $13^{\text {th }}, 2019$ \\ Revised Aug $23^{\text {th }}, 2019$ \\ Accepted Sept 26 ${ }^{\text {th }}, 2019$
}

\section{Keyword:}

Gold Price Prediction

Linear Regression

Predictive Modeling

Trader

XAUUSD

\begin{abstract}
Gold is an investment instrument that is quite safe from inflationary attacks, and gold is one aspect of initiating investment. Can by buying gold in physical form and then selling when the price has risen high or by digitally investing gold. One of them is by trading gold online. To maximize the benefits of gold trading, a gold price prediction (XAUUSD) is needed for traders. This study aims to (1) Analyze various factors that influence the price of gold (2) Provide recommendations about the prediction of gold prices. Materials that will be used as objects of research to produce gold price predictions include historical XAUUSD (Gold) data itself, historical crude oil data, historical dollar data (USD IDR) and BI 7-Day Repo Rate (BI Rate). ), in producing the prediction of the gold price used Mining Predictive Modeling data using the linear regression function. The results to be achieved from this study is to provide accurate gold price predictions so that it can be used as a reference in making decisions to buy / sell positions in trading. The prediction of the XAUUSD gold price generated is expected to provide significant interest to the investment players (traders) in order to maximize the profit generated. From the results of the trading tests that have been carried out, the implementation of predictive modeling data mining using a linear regression function produces recommendations for gold price predictions (XAUUSD) with an accuracy of $85 \%$.
\end{abstract}

Copyright $\odot 2019$ Puzzle Research Data Technology

\section{Corresponding Author:}

Iman Priyadi,

Program Studi Teknik Informatika,

Magister Ilmu Komputer, Universitas Putra Indonesia "YPTK" Padang,

Jl. Raya Lubuk Begalung, Padang, Sumatera Barat.

Email: iman.priyadi@merantikab.go.id

DOI: http://dx.doi.org/10.24014/ijaidm.v2i2.6864

\section{PENDAHULUAN}

Beragam produk investasi hadir pada saat ini, mulai dari deposito, reksadana, sukuk, asuransi, emas, tanah, saham dll. Beragam investasi tersebut hadir dengan membawa berbagai kelebihan dan kekurangannya. Untuk itu seorang Investor memerlukan sebuah perhitungan yang tepat dalam memilih produk investasi yang ada. Menetapkan tujuan investasi keuangannya, jangka waktu investasi yang diinginkan dan memahami resiko investasi yang dapat ditoleransi. Produk investasi berupa emas merupakan salah satu produk yang cukup banyak diminati oleh investor untuk mendapatkan keuntungan. Emas dipilih dikarenakan emas memiliki nilai yang cenderung naik setiap tahunnya dan lebih tahan terhadap inflasi dibandingkan dengan berbagai jenis investasi lainnya. Secara umum Investasi emas terbagi menjadi dua yaitu investasi emas berbentuk fisik dan Digital.

Investasi emas dalam bentuk digital masih terbagi menjadi beberapa jenis diantaranya sertifikat emas, tabungan emas dan salah satunya adalah perdagangan emas (Gold Trading). Gold Trading adalah perdagangan emas yang dilakukan secara online di pasar foreign exchange (forex) tanpa melibatkan perpindahan aset emas secara fisik. Untuk dapat memaksimalkan keuntungan yang diperoleh dan guna 
meminimalkan potensi kerugian yang ada, sebagai seorang Investor (Gold trader), membutuhkan penggunaan strategi trading emas yang tepat. Strategi ini dilakukan dengan mengimplementasikan konsep data mining. Dengan melibatkan beberapa indikator tambahan selain harga emas itu sendiri yaitu meliputi harga penutupan, harga pembukaan, harga tertinggi, harga terendah dari nilai tukar dollar terhadap rupiah, harga minyak mentah dunia dan BI Rate.

Data mining adalah salah satu bentuk implementasi yang diterapkan untuk mencari sebuah model dan pola yang mampu melakukan prediksi pada suatu data berdasarkan data sebelumnya di periode waktu tertentu (Guntur M., Julius S. dan Yuhandri, 2018). Data Mining adalah Penambangan data, dalam istilah sederhana adalah menemukan pola yang berguna dalam data dan terdapat berbagai macam definisi dan kriteria untuk penambangan data. Data mining juga disebut sebagai knowledge discovery, machine learning, dan predictive analytics (Kotu V. dan Deshpande B., 2015).

Metodologi formal dalam melakukan penambangan data meliputi langkah-langkah dasar berikut (George R., Richard O. dan Daniel O., 2018) : menentukan sifat dan struktur representasi dari kumpulan data, menentukan cara menghitung data, membandingkan seberapa baik representasi yang berbeda sesuai dengan data, memilih proses algoritma untuk mengoptimalkan fungsi scoring, menentukan prinsip manajemen data yang diperlukan untuk mengimplementasikan algoritma secara efisien.

Adapun untuk menghasilkan rekomendasi prediksi harga emas yang tepat dan akurat metode yang digunakan adalah data mining predictive modelling dengan menggunakan fungsi regresi linear. Sedangkan aplikasi yang digunakan adalah Rapidminer.

\section{METODE PENELITIAN}

Kerangka kerja penelitian ini merupakan langkah-langkah yang akan dilakukan dalam melakukan penyelesaian masalah yang akan dibahas. Adapun detail kerangka kerja penelitian tahapan demi tahapannya dapat dilihat seperti gambar yang ada dibawah ini :

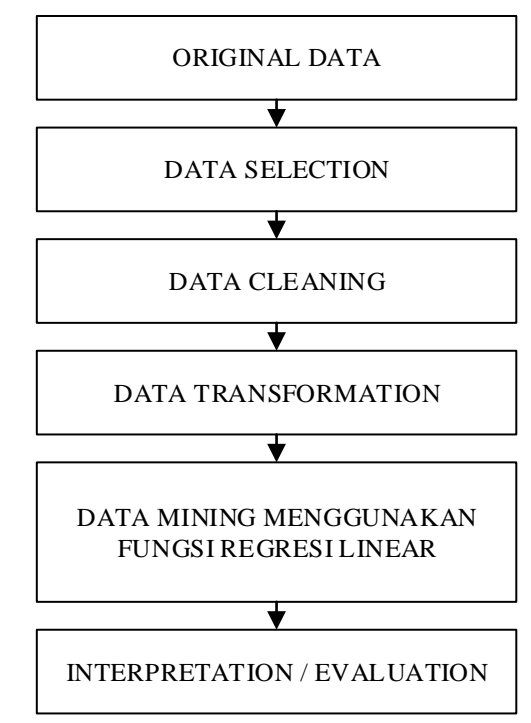

Gambar 1. Kerangka Kerja Penelitian

Data yang digunakan dalam penelitian ini dikumpulkan dari berbagai sumber yang ada, data-data tersebut akan digunakan sebagai data training dan data testing. Data historis XAUUSD (Gold), Data historis minyak mentah berjangka (Crude Oil) dan Data historis dollar (USD IDR). Data yang digunakan diambil dari website investing.com yang merupakan website yang menyediakan informasi mendalam mengenai Indeks \& Saham, Komoditas, Valuta Asing, Futures \& Opsi, serta harga \& Obligasi, di url :

1) https://investing.com/currencies/xau-usd-historical-data (Gold Price, Gold Open, Gold High, Gold Low)

2) https://investing.com/commodities/crude-oil-historical-data. (Crude Oil Price, Crude Oil Open, Crude Oil High, Crude Oil Low)

3) https://investing.com/currencies/usd-idr-historical-data (Dollar Price, Dollar Open, Dollar High, Dollar Low)

Selain itu terdapat data BI 7-Day Repo Rate, diambil dari website resmi Bank Indonesia (BI) di url https://www.bi.go.id/id/moneter/bi-7day-RR/data/Contents/Default.aspx. 


\section{HASIL DAN ANALISA}

\subsection{Data Original}

Data yang digunakan adalah data yang diambil dalam rentang 4 (empat) bulan dimulai dari tanggal 1 Oktober 2018 - 31 Januari 2019, data tersebut meliputi : Data historis XAUUSD (Gold) terbagi menjadi (Date, Gold Price (\$), Gold Open (\$), Gold High (\$), Gold Low (\$), Gold Change \%), Data historis Crude Oil yang terbagi menjadi (Date, Crude Oil Price (\$), Crude Oil Open (\$), Crude Oil High (\$), Crude Oil Low (\$), Crude Oil Vol (\$), Crude Oil Change \%), Data historis dollar (USD IDR) yang terbagi menjadi (Date, Dollar Price (Rp), Dollar Open (Rp), Dollar High (Rp), Dollar Low (Rp), Dollar Change \%) dan data BI 7Day Repo Rate (BI Rate).

\subsection{Data Selection}

Data original yang ada pada tahap ini setalah melalui tahap data selection menjadi seperti berikut : (Date, Gold Price (\$), Gold Open (\$), Gold High (\$), Gold Low (\$)), Data historis Crude Oil (Crude Oil Price (\$), Crude Oil Open (\$), Crude Oil High (\$), Crude Oil Low (\$)), Data historis dollar (USD IDR) (Date, Dollar Price (Rp), Dollar Open (Rp), Dollar High (Rp), Dollar Low (Rp)) dan data BI 7-Day Repo Rate (BI Rate).

\subsection{Data Cleaning}

Setelah dilakukan proses data selection selanjutnya adalah melakukan proses data cleaning dari data yang telah diseleksi. Dari keseluruhan data tersebut diproses data cleaning dengan cara antara lain membuang duplikasi data yang ada (Remove Duplicate) dan melengkapi data yang tidak lengkap (Is Not Missing). Hasil dari proses Data Cleaning yang dilakukan tidak menghasilkan perubahan apapun, hal ini disebabkan data yang ada tidak ada duplikasi maupun data yang tidak lengkap.

\subsection{Data Transformation}

Setelah proses data cleaning dilakukan selanjutnya adalah proses data transformation. Pada tahapan ini data diubah atau digabung ke dalam format yang sesuai untuk proses dalam data mining. Data-data yang ada yang meliputi : Data XAUUSD (Gold) yang terdiri (Date, Gold Price (\$), Gold Open (\$), Gold High (\$), Gold Low (\$)), Data historis Crude Oil (Crude Oil Price (\$), Crude Oil Open (\$), Crude Oil High (\$), Crude Oil Low (\$)), Data historis dollar (USD IDR) (Date, Dollar Price (Rp), Dollar Open (Rp), Dollar High (Rp), Dollar Low (Rp)) dan data BI 7-Day Repo Rate (BI Rate). Data tersebut ditransformasikan menjadi bentuk seperti tahapan pada tabel dibawah ini.

Tabel 1. Data Gold (XAUUSD)

\begin{tabular}{ccccc}
\hline \multicolumn{5}{c}{ Gold } \\
\hline Date & Price $(\$)$ & $\begin{array}{c}\text { Open } \\
(\$)\end{array}$ & $\begin{array}{c}\text { High } \\
(\$)\end{array}$ & Low $(\$)$ \\
31-Jan-19 & $1,321.13$ & $1,319.32$ & $1,326.32$ & $1,317.53$ \\
30-Jan-19 & $1,319.32$ & $1,310.79$ & $1,323.43$ & $1,309.10$ \\
29-Jan-19 & $1,310.78$ & $1,304.01$ & $1,312.03$ & $1,302.79$ \\
. &. &. &. &. \\
3-Oct-18 & $1,197.37$ & $1,203.39$ & $1,208.77$ & $1,196.71$ \\
2-Oct-18 & $1,203.10$ & $1,189.20$ & $1,208.65$ & $1,188.57$ \\
1-Oct-18 & $1,188.46$ & $1,192.55$ & $1,192.95$ & $1,184.94$ \\
\hline
\end{tabular}

Tabel 3. Data BI Rate

\begin{tabular}{c}
\hline BI Rate \% \\
\hline 6.00 \\
6.00 \\
6.00 \\
5.75 \\
5.75 \\
5.75 \\
\hline
\end{tabular}

Tabel 2. Data Dollar (USD IDR)

\begin{tabular}{cccc}
\hline \multicolumn{4}{c}{ Dollar } \\
\hline Price & Open & High & Low $(\mathrm{Rp})$ \\
$(\mathrm{Rp})$ & $(\mathrm{Rp})$ & $(\mathrm{Rp})$ & \\
$13,972.50$ & $14,135.00$ & $14,135.00$ & $13,960.00$ \\
$14,130.00$ & $14,097.00$ & $14,132.00$ & $14,085.00$ \\
$14,095.00$ & $14,070.00$ & $14,097.00$ & $14,070.00$ \\
. &. &. &. \\
$15,075.00$ & $15,050.00$ & $15,095.00$ & $15,050.00$ \\
$15,045.00$ & $14,915.00$ & $15,053.00$ & $14,915.00$ \\
$14,910.00$ & $14,885.00$ & $14,915.00$ & $14,885.00$ \\
\hline
\end{tabular}

Tabel 4. Minyak Mentah (Data Crude Oil)

\begin{tabular}{cccc}
\hline \multicolumn{4}{c}{ Crude Oil } \\
\hline $\begin{array}{c}\text { Price } \\
(\$)\end{array}$ & $\begin{array}{c}\text { Open } \\
(\$)\end{array}$ & $\begin{array}{c}\text { High } \\
(\$)\end{array}$ & $\begin{array}{c}\text { Low } \\
(\$)\end{array}$ \\
\hline 53.90 & 54.50 & 55.37 & 53.62 \\
54.23 & 53.24 & 54.93 & 53.09 \\
53.31 & 52.12 & 53.93 & 51.84 \\
. &. &. &. \\
76.41 & 75.12 & 76.90 & 74.30 \\
75.23 & 75.42 & 75.91 & 74.93 \\
75.30 & 73.29 & 75.77 & 72.95 \\
\hline
\end{tabular}

Maka transformasi pada 4 data tabel diatas akan dirangkum menjadi tabel 5. melalui proses transformasi dibawah ini : 
Tabel 5. Hasil Transformasi

\begin{tabular}{|c|c|c|c|c|c|c|c|c|c|c|c|c|c|}
\hline \multicolumn{5}{|c|}{ Gold } & \multicolumn{4}{|c|}{ Dollar } & \multirow{2}{*}{$\begin{array}{c}\text { BI } \\
\text { Rate } \\
\% \\
\end{array}$} & \multicolumn{4}{|c|}{ Crude Oil } \\
\hline Date & $\begin{array}{l}\text { Price } \\
(\$)\end{array}$ & $\begin{array}{c}\text { Open } \\
(\$)\end{array}$ & $\begin{array}{l}\text { High } \\
(\$)\end{array}$ & Low (\$) & $\begin{array}{c}\text { Price } \\
(\mathrm{Rp})\end{array}$ & $\begin{array}{c}\text { Open } \\
\text { (Rp) }\end{array}$ & $\begin{array}{c}\text { High } \\
(\mathrm{Rp})\end{array}$ & Low (Rp) & & $\begin{array}{c}\text { Price } \\
(\$)\end{array}$ & $\begin{array}{c}\text { Open } \\
(\$)\end{array}$ & $\begin{array}{c}\text { High } \\
(\$)\end{array}$ & $\begin{array}{c}\text { Low } \\
(\$)\end{array}$ \\
\hline 31-Jan-19 & $1,321.13$ & $1,319.32$ & $1,326.32$ & $1,317.53$ & $13,972.50$ & $14,135.00$ & $14,135.00$ & $13,960.00$ & 6.00 & 53.90 & 54.50 & 55.37 & 53.62 \\
\hline 30-Jan-19 & $1,319.32$ & $1,310.79$ & $1,323.43$ & $1,309.10$ & $14,130.00$ & $14,097.00$ & $14,132.00$ & $14,085.00$ & 6.00 & 54.23 & 53.24 & 54.93 & 53.09 \\
\hline 29-Jan-19 & $1,310.78$ & $1,304.01$ & $1,312.03$ & $1,302.79$ & $14,095.00$ & $14,070.00$ & $14,097.00$ & $14,070.00$ & 6.00 & 53.31 & 52.12 & 53.93 & 51.84 \\
\hline & & & & & & $\dot{-}$ & & & & & & & 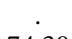 \\
\hline 3-Oct-18 & $1,197.37$ & $1,203.39$ & $1,208.77$ & $1,196.71$ & $15,075.00$ & $15,050.00$ & $15,095.00$ & $15,050.00$ & 5.75 & 76.41 & 75.12 & 76.90 & 74.30 \\
\hline 2-Oct-18 & $1,203.10$ & $1,189.20$ & $1,208.65$ & $1,188.57$ & $15,045.00$ & $14,915.00$ & $15,053.00$ & $14,915.00$ & 5.75 & 75.23 & 75.42 & 75.91 & 74.93 \\
\hline 1-Oct-18 & $1,188.46$ & $1,192.55$ & $1,192.95$ & $1,184.94$ & $14,910.00$ & $14,885.00$ & $14,915.00$ & $14,885.00$ & 5.75 & 75.30 & 73.29 & 75.77 & 72.95 \\
\hline
\end{tabular}

\subsection{Data Mining Menggunakan Fungsi Regresi Linear}

Tahapan ini merupakan tahapan yang penting di mana teknik data mining diterapkan untuk mengekstraksi pola yang berpotensi bermanfaat / proses mencari pola atau informasi menarik dalam data terpilih dengan menggunakan teknik, metode atau fungsi tertentu. Adapun dalam penerapannya terbagi menjadi dua yaitu tahapan perhitungan secara manual dan juga menggunakan aplikasi rapidminer.

\subsubsection{Tahapan Perhitungan Manual}

Adapun tahapan perhitungan manual tersebut meliputi :

1. Menentukan $\mathrm{x}_{1} \ldots \mathrm{x}_{\mathrm{n}}$ (variabel independen) dan $\mathrm{y}$ (variabel dependen / nilai yang diprediksi)

2. Menghitung: $\left(\mathrm{x}_{1}\right)^{2} \ldots\left(\mathrm{x}_{\mathrm{n}}\right)^{2}$

3. Menghitung: $\mathrm{x}_{1} * \mathrm{x}_{2}, \mathrm{x}_{1} * \mathrm{x}_{\mathrm{n}}, \ldots \mathrm{x}_{1} * \mathrm{y}, \mathrm{x}_{\mathrm{n}} * \mathrm{y}$

4. Menghitung: $\Sigma \mathrm{x}_{1}, \ldots \Sigma \mathrm{x}_{\mathrm{n}}$ dan $\Sigma \mathrm{y}$

5. Menghitung : $\Sigma\left(\mathrm{x}_{1}\right)^{2}, \ldots \Sigma\left(\mathrm{x}_{\mathrm{n}}\right)^{2}$

6. Menghitung : $\Sigma \mathrm{x}_{1} * \mathrm{x}_{2}, \Sigma \mathrm{x}_{1} * \mathrm{x}_{\mathrm{n}}, \ldots \Sigma \mathrm{x}_{1} * \mathrm{y}, \Sigma \mathrm{x}_{\mathrm{n}} * \mathrm{y}$

7. Menghitung kedalam rumus persamaan mencari a (konstanta), b1 ... bn (Koefisien regresi)

8. Menghitung nilai a (konstanta), b1 ... bn (Koefisien regresi) menggunakan perhitungan matriks

9. Menghitung dalam persamaan regresi linear

Pada tahapan ini telah dihasilkan prediksi setelah melalui proses penerapan fungsi regresi linear dan hasil prediksi tersebut digunakan sebagai bahan perbandingan.

Tabel 6. Hasil Prediksi Perhitungan Secara Manual

\begin{tabular}{lcc}
\hline No & Tanggal & Hasil Prediksi (\$) \\
\hline 1 & 12 Februari 2019 & 1311.22 \\
2 & 13 Februari 2019 & 1314.88 \\
3 & 14 Februari 2019 & 1311.49 \\
4 & 15 Februari 2019 & 1315.96 \\
5 & 18 Februari 2019 & 1326.64 \\
6 & 19 Februari 2019 & 1326.74 \\
7 & 20 Februari 2019 & 1340.84 \\
\hline
\end{tabular}

\subsubsection{Tahapan Menggunakan Aplikasi Rapidminer}

Pada tahapan ini akan dibahas tentang penerapan fungsi regresi linear dengan menggunakan aplikasi rapidminer sehingga akan menghasilkan rekomendasi prediksi harga emas yang nantinya akan digunakan dan diujicoba secara langsung pada trading emas online menggunakan metatrader guna melihat tingkat akurasi yang dihasilkannya. Adapun proses menghasilkan prediksi dan uji coba secara langsung dimulai pada tanggal 12 Februari - 20 Februari 2019.

Adapun proses pada Rapidminer seperti terlihat pada gambar dibawah ini, pada proses ini menghasilkan prediksi XAUUSD (Gold) mengarah ke harga 1310.860 pada tanggal 12 februari 2019. 


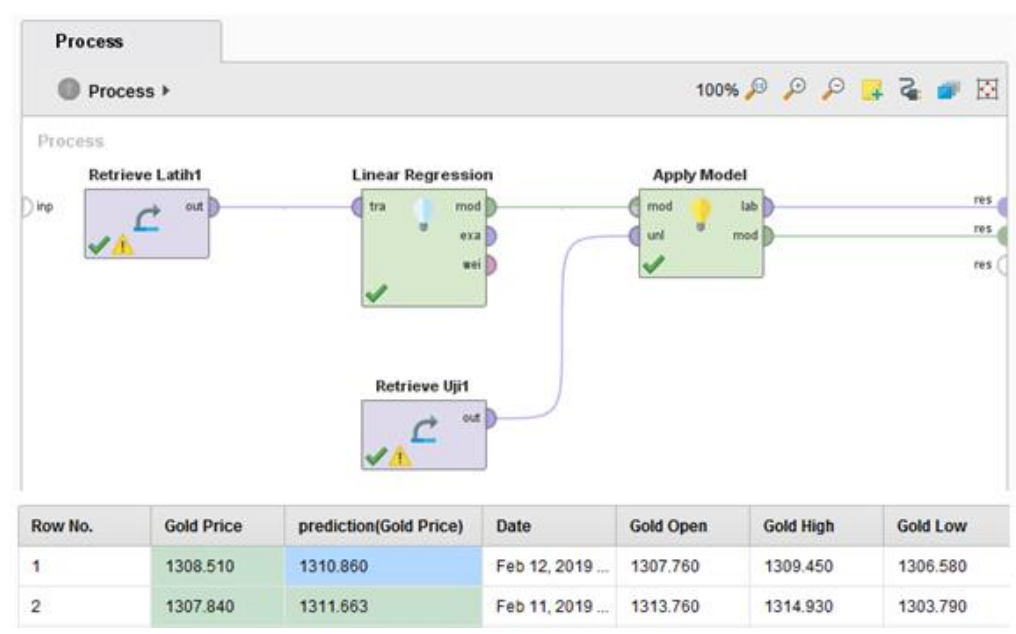

Gambar 2. Proses Penerapan Regresi Linear Tanggal 12 Februari 2019

\subsubsection{Uji Tanggal 12 Februari 2019}

Tabel 7. Data Uji untuk Hasilkan Rekomendasi Prediksi pada Tanggal 12 Februari 2019

\begin{tabular}{|c|c|c|c|c|c|c|c|c|c|c|c|c|c|}
\hline \multicolumn{5}{|c|}{ Gold } & \multicolumn{4}{|c|}{ Dollar } & $\overline{B I}$ & \multicolumn{4}{|c|}{ Crude Oil } \\
\hline Date & $\begin{array}{l}\text { Price } \\
(\$)\end{array}$ & $\begin{array}{l}\text { Open } \\
(\$)\end{array}$ & $\begin{array}{l}\text { High } \\
\text { (\$) }\end{array}$ & $\begin{array}{l}\text { Low } \\
(\$)\end{array}$ & $\begin{array}{l}\text { Price } \\
\text { (Rp) }\end{array}$ & $\begin{array}{c}\text { Open } \\
\text { (Rp) }\end{array}$ & $\begin{array}{l}\text { High } \\
\text { (Rp) }\end{array}$ & $\begin{array}{l}\text { Low } \\
\text { (Rp) }\end{array}$ & $\begin{array}{c}\text { Rate } \\
\%\end{array}$ & $\begin{array}{l}\text { Price } \\
(\$)\end{array}$ & $\begin{array}{c}\text { Open } \\
(\$)\end{array}$ & $\begin{array}{c}\text { High } \\
(\$)\end{array}$ & $\begin{array}{l}\text { Low } \\
(\$)\end{array}$ \\
\hline 12-Feb-19 & $1.308,51$ & $1.307,76$ & $1.309,45$ & $1.306,58$ & $14.087,50$ & $14.085,00$ & $14.097,50$ & $14.072,50$ & 6,00 & 52,78 & 52,42 & 52,91 & 52,38 \\
\hline 11-Feb-19 & $1.307,84$ & $1.313,76$ & $1.314,93$ & $1.303,79$ & $14.040,00$ & $13.985,00$ & $14.047,50$ & $13.985,00$ & 6,00 & 52,41 & 52,50 & 52,67 & 51,24 \\
\hline 8-Feb-19 & $1.314,26$ & $1.310,53$ & $1.315,69$ & $1.307,85$ & $13.965,00$ & $13.975,00$ & $14.000,00$ & $13.948,00$ & 6,00 & 52,72 & 52,59 & 52,99 & 52,08 \\
\hline 7-Feb-19 & $1.310,51$ & $1.306,70$ & $1.312,00$ & $1.302,88$ & $13.972,50$ & $13.927,50$ & $13.987,50$ & $13.927,50$ & 6,00 & 52,64 & 53,94 & 54,21 & 51,80 \\
\hline 6-Feb-19 & $1.306,69$ & $1.315,06$ & $1.315,88$ & $1.305,76$ & $13.922,00$ & $13.950,00$ & $13.950,00$ & $13.890,00$ & 6,00 & 54,01 & 53,73 & 54,30 & 52,86 \\
\hline 5-Feb-19 & $1.315,06$ & $1.311,78$ & $1.316,93$ & $1.310,80$ & $13.955,00$ & $13.955,00$ & $13.955,00$ & $13.955,00$ & 6,00 & 53,66 & 54,86 & 55,21 & 53,47 \\
\hline 4-Feb-19 & $1.311,83$ & $1.317,18$ & $1.317,59$ & $1.308,72$ & $13.955,00$ & $13.950,00$ & $13.995,00$ & $13.940,00$ & 6,00 & 54,56 & 55,32 & 55,75 & 53,29 \\
\hline 1-Feb-19 & $1.317,65$ & $1.321,12$ & $1.323,58$ & $1.316,19$ & $13.940,00$ & $13.945,00$ & $13.985,00$ & $13.940,00$ & 6,00 & 55,26 & 54,01 & 55,66 & 53,37 \\
\hline
\end{tabular}

\subsubsection{Uji Tanggal 13 Februari 2019}

Tabel 8. Data uji untuk hasilkan rekomendasi prediksi pada tanggal 13 Februari 2019

\begin{tabular}{|c|c|c|c|c|c|c|c|c|c|c|c|c|c|}
\hline \multicolumn{5}{|c|}{ Gold } & \multicolumn{4}{|c|}{ Dollar } & \multirow{2}{*}{$\begin{array}{c}\text { BI } \\
\text { Rate } \\
\%\end{array}$} & \multicolumn{4}{|c|}{ Crude Oil } \\
\hline Date & $\begin{array}{l}\text { Price } \\
(\$)\end{array}$ & $\begin{array}{c}\text { Open } \\
(\$)\end{array}$ & $\begin{array}{c}\text { High } \\
(\$)\end{array}$ & $\begin{array}{c}\text { Low } \\
(\$)\end{array}$ & $\begin{array}{c}\text { Price } \\
\text { (Rp) }\end{array}$ & $\begin{array}{c}\text { Open } \\
\text { (Rp) }\end{array}$ & $\begin{array}{l}\text { High } \\
\text { (Rp) }\end{array}$ & $\begin{array}{l}\text { Low } \\
\text { (Rp) }\end{array}$ & & $\begin{array}{c}\text { Price } \\
(\$)\end{array}$ & $\begin{array}{c}\text { Open } \\
(\$)\end{array}$ & $\begin{array}{c}\text { High } \\
(\$)\end{array}$ & $\begin{array}{c}\text { Low } \\
(\$)\end{array}$ \\
\hline 13-Feb-19 & $1.312,34$ & $1.310,26$ & $1.312,77$ & $1.309,43$ & $14.034,50$ & $14.030,00$ & $14.040,00$ & $14.020,00$ & 6,00 & 53,65 & 53,48 & 53,75 & 53,41 \\
\hline 12-Feb-19 & $1.310,35$ & $1.307,76$ & $1.314,81$ & $1.306,58$ & $14.087,50$ & $14.085,00$ & $14.097,50$ & $14.037,50$ & 6,00 & 53,49 & 52,42 & 54,05 & 52,38 \\
\hline 11-Feb-19 & $1.307,84$ & $1.313,76$ & $1.314,93$ & $1.303,79$ & $14.040,00$ & $13.985,00$ & $14.047,50$ & $13.985,00$ & 6,00 & 52,41 & 52,50 & 52,67 & 51,24 \\
\hline 8-Feb-19 & $1.314,26$ & $1.310,53$ & $1.315,69$ & $1.307,85$ & $13.965,00$ & $13.975,00$ & $14.000,00$ & $13.948,00$ & 6,00 & 52,72 & 52,59 & 52,99 & 52,08 \\
\hline 7-Feb-19 & $1.310,51$ & $1.306,70$ & $1.312,00$ & $1.302,88$ & $13.972,50$ & $13.927,50$ & $13.987,50$ & $13.927,50$ & 6,00 & 52,64 & 53,94 & 54,21 & 51,80 \\
\hline 6-Feb-19 & $1.306,69$ & $1.315,06$ & $1.315,88$ & $1.305,76$ & $13.922,00$ & $13.950,00$ & $13.950,00$ & $13.890,00$ & 6,00 & 54,01 & 53,73 & 54,30 & 52,86 \\
\hline 5-Feb-19 & $1.315,06$ & $1.311,78$ & $1.316,93$ & $1.310,80$ & $13.955,00$ & $13.955,00$ & $13.955,00$ & $13.955,00$ & 6,00 & 53,66 & 54,86 & 55,21 & 53,47 \\
\hline 4-Feb-19 & $1.311,83$ & $1.317,18$ & $1.317,59$ & $1.308,72$ & $13.955,00$ & $13.950,00$ & $13.995,00$ & $13.940,00$ & 6,00 & 54,56 & 55,32 & 55,75 & 53,29 \\
\hline 1-Feb-19 & $1.317,65$ & $1.321,12$ & $1.323,58$ & $1.316,19$ & $13.940,00$ & $13.945,00$ & $13.985,00$ & $13.940,00$ & 6,00 & 55,26 & 54,01 & 55,66 & 53,37 \\
\hline
\end{tabular}

Akan dilakukan uji coba RapidMiner hingga tanggal 20 Februari 2019 untuk mencapai hasil maksimal sebagai perbandingan rekomendasi prediksi dengan hasil di metatrader.

\subsubsection{Uji Tanggal 20 Februari 2019}

Tabel 9. Data uji untuk hasilkan rekomendasi prediksi pada tanggal 20 Februari 2019

\begin{tabular}{|c|c|c|c|c|c|c|c|c|c|c|c|c|c|}
\hline \multicolumn{5}{|c|}{ Gold } & \multicolumn{4}{|c|}{ Dollar } & \multirow{2}{*}{$\begin{array}{c}\text { BI } \\
\text { Rate } \\
\%\end{array}$} & \multicolumn{4}{|c|}{ Crude Oil } \\
\hline Date & $\begin{array}{l}\text { Price } \\
(\$)\end{array}$ & $\begin{array}{c}\text { Open } \\
(\$)\end{array}$ & $\begin{array}{l}\text { High } \\
(\$)\end{array}$ & $\begin{array}{c}\text { Low } \\
(\$)\end{array}$ & $\begin{array}{c}\text { Price } \\
\text { (Rp) }\end{array}$ & $\begin{array}{c}\text { Open } \\
\text { (Rp) }\end{array}$ & $\begin{array}{l}\text { High } \\
(\mathrm{Rp})\end{array}$ & $\begin{array}{l}\text { Low } \\
\text { (Rp) }\end{array}$ & & $\begin{array}{c}\text { Price } \\
(\$)\end{array}$ & $\begin{array}{c}\text { Open } \\
(\$)\end{array}$ & $\begin{array}{c}\text { High } \\
(\$)\end{array}$ & $\begin{array}{c}\text { Low } \\
(\$)\end{array}$ \\
\hline 20-Feb-19 & $1.341,83$ & $1.339,67$ & $1.346,79$ & $1.339,45$ & $14.047,50$ & $14.082,50$ & $14.082,50$ & $14.040,00$ & 6,00 & 56,49 & 56,31 & 56,77 & 56,16 \\
\hline 19-Feb-19 & $1.339,63$ & $1.326,51$ & $1.341,93$ & $1.322,95$ & $14.102,00$ & $14.105,00$ & $14.130,00$ & $14.099,50$ & 6,00 & 56,30 & 56,27 & 56,62 & 55,66 \\
\hline 18-Feb-19 & $1.326,52$ & $1.321,33$ & $1.327,69$ & $1.320,97$ & $14.106,50$ & $14.120,00$ & $14.120,00$ & $14.080,00$ & 6,00 & 56,27 & 56,33 & 56,73 & 56,12 \\
\hline $15-F e b-19$ & $1.321,41$ & $1.312,01$ & $1.322,59$ & $1.311,50$ & $14.142,50$ & $14.092,50$ & $14.157,50$ & $14.092,50$ & 6,00 & 55,59 & 54,48 & 55,87 & 54,24 \\
\hline 14-Feb-19 & $1.312,00$ & $1.307,74$ & $1.314,41$ & $1.302,57$ & $14.057,50$ & $14.027,50$ & $14.057,50$ & $14.007,50$ & 6,00 & 54,58 & 53,98 & 54,69 & 53,12 \\
\hline 13-Feb-19 & $1.307,74$ & $1.310,26$ & $1.318,24$ & $1.305,12$ & $14.057,50$ & $14.030,00$ & $14.060,00$ & $14.010,00$ & 6,00 & 53,98 & 53,48 & 54,60 & 53,29 \\
\hline
\end{tabular}




\begin{tabular}{|c|c|c|c|c|c|c|c|c|c|c|c|c|c|}
\hline 12-Feb-19 & $1.310,35$ & $1.307,76$ & $1.314,81$ & $1.306,58$ & $14.087,50$ & $14.085,00$ & $14.097,50$ & $14.037,50$ & 6,00 & 53,49 & 52,42 & 54,05 & 52,38 \\
\hline 11-Feb-19 & $1.307,84$ & $1.313,76$ & $1.314,93$ & $1.303,79$ & $14.040,00$ & $13.985,00$ & $14.047,50$ & $13.985,00$ & 6,00 & 52,41 & 52,50 & 52,67 & 51,24 \\
\hline 8-Feb-19 & $1.314,26$ & $1.310,53$ & $1.315,69$ & $1.307,85$ & $13.965,00$ & $13.975,00$ & $14.000,00$ & $13.948,00$ & 6,00 & 52,72 & 52,59 & 52,99 & 52,08 \\
\hline 7-Feb-19 & $1.310,51$ & $1.306,70$ & $1.312,00$ & $1.302,88$ & $13.972,50$ & $13.927,50$ & $13.987,50$ & $13.927,50$ & 6,00 & 52,64 & 53,94 & 54,21 & 51,80 \\
\hline 6-Feb-19 & $1.306,69$ & $1.315,06$ & $1.315,88$ & $1.305,76$ & $13.922,00$ & $13.950,00$ & $13.950,00$ & $13.890,00$ & 6,00 & 54,01 & 53,73 & 54,30 & 52,86 \\
\hline 5-Feb-19 & $1.315,06$ & $1.311,78$ & $1.316,93$ & $1.310,80$ & $13.955,00$ & $13.955,00$ & $13.955,00$ & $13.955,00$ & 6,00 & 53,66 & 54,86 & 55,21 & 53,47 \\
\hline 4-Feb-19 & $1.311,83$ & $1.317,18$ & $1.317,59$ & $1.308,72$ & $13.955,00$ & $13.950,00$ & $13.995,00$ & $13.940,00$ & 6,00 & 54,56 & 55,32 & 55,75 & 53,29 \\
\hline 1-Feb-19 & $1.317,65$ & $1.321,12$ & $1.323,58$ & $1.316,19$ & $13.940,00$ & $13.945,00$ & $13.985,00$ & $13.940,00$ & 6,00 & 55,26 & 54,01 & 55,66 & 53,37 \\
\hline
\end{tabular}

\subsubsection{Implementasi di Metatrader}



Gambar 3. Proses Penerapan Regresi Linear tanggal 20 Februari 2019

Tabel 10. Perbandingan Prediksi dan Hasil di Metatrader

\begin{tabular}{ccccc}
\hline No & Tanggal & $\begin{array}{c}\text { Prediksi } \\
\text { Rapidminer }(\$)\end{array}$ & $\begin{array}{c}\text { Hasil Trading di } \\
\text { Metatrader }(\$)\end{array}$ & Profit (Pips) \\
\hline 1 & 12 Februari 2019 & 1310.86 & 1310.86 & 272 \\
2 & 13 Februari 2019 & 1313.81 & 1313.81 & 111 \\
3 & 14 Februari 2019 & 1312.26 & 1312.26 & 384 \\
4 & 15 Februari 2019 & 1315.05 & 1315.05 & 286 \\
5 & 18 Februari 2019 & 1325.03 & 1325.03 & 30 \\
6 & 19 Februari 2019 & 1327.74 & 1327.74 & 376 \\
7 & 20 Februari 2019 & 1341.62 & 1345.34 & -279 \\
\hline
\end{tabular}

Tabel 11. Hasil Pengujian Trading tanggal 12-20 Februari 2019

\begin{tabular}{cc}
\hline Tanggal & Keterangan \\
\hline $12-$ Februari & Berhasil \\
$13-$ Februari & Berhasil \\
$14-$ Februari & Berhasil \\
$15-$ Februari & Berhasil \\
$18-$ Februari & Berhasil \\
$19-$ Februari & Berhasil \\
$20-$ Februari & Tidak Berhasil \\
\hline
\end{tabular}

Tingkat akurasi rekomendasi prediksi yang diimplementasikan di metatrader, dari data yang sebelumnya dihasilkan dengan menggunakan fungsi regresi linear selama pengujian tujuh (7) hari dapat disimpulkan:

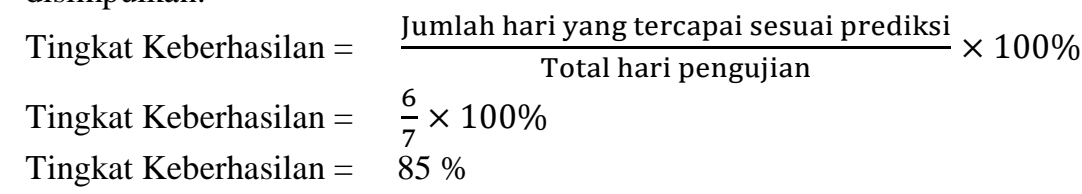

\section{KESIMPULAN}

Berdasarkan hasil dari penelitian dan pengujian yang dilakukan, maka dapat ditarik beberapa kesimpulan diantaranya adalah :

1. Dari pengolahan data yang ada, setelah melalui proses penerapan metode data mining predictive modelling menggunakan fungsi regresi linear telah dihasilkan rekomendasi prediksi yang dapat 
digunakan sebagai acuan untuk trading pada metatrader. Hasil rekomendasi tersebut menghasilkan pencapaian akurasi sebesar $85 \%$.

2. Selain harga emas itu sendiri (Gold Price, Gold Open, Gold High, Gold Low) ternyata nilai tukar Dollar terhadap Rupiah (Dollar Price, Dollar Open, Dollar High, Dollar Low), BI-7 Repo rate (BI Rate) dan harga minyak mentah dunia (Crude Oil Price, Crude Oil Open, Crude Oil High dan Crude Oil Low) memberikan pengaruh yang sangat signifikan terhadap pergerakan harga emas (XAUUSD) jika dilihat dari hasil yang telah dicapai pada saat dilakukan trading dengan menerapkan hasil rekomendasi prediksi.

3. Dengan tingkat akurasi yang mencapai $85 \%$, maka rekomendasi prediksi harga emas yang diimplementasikan dengan metode data mining predictive modelling menggunakan fungsi regresi linear, disimpulkan dapat memberikan profit yang optimal terhadap investor (Gold Trader).

\section{REFERENCES}

[1] Guntur M, Santony J., Yuhandri, Prediksi Harga Emas dengan Menggunakan Metode Naive Bayes dalam Investasi untuk Meminimalisasi Resiko. 2018; JURNAL RESTI, 2(1), pp. 354-360

[2] Berry M.J.A., Linof G.S., Data Mining Techniques For Marketing, Sales, and Customer Relationship Management. Indianapolis, Indiana: Wiley Publishing 2004.

[3] Kotu V., Deshpande B., Predictive Analitics and Data Mining Concepts and Practice with Rapidminer. 225 Wyman Street Waltham MA 02451 USA: Morgan Kaufmann. 2015.

[4] Nofriansyah D., Konsep Data Mining Sistem Pendukung Keputusan. Yogyakarta: DeePublish. 2014.

[5] Salim J., Panduan Praktis Bermain Valas Lewat Internet. Jl. Haji Montong No. 57 Ciganjur Jagaraksa Jakarta Selatan: MediaKita. 2008.

[6] Smart S.B., Gitman L.J., Joehnk M.D., Fundamentals of Investing. England: Pearson. 2014.

[7] Sudaryo Y., Yudanegara A., Investasi Bank dan Lembaga Keuangan. Jl. Beo 38-40 Yogyakarta: Andi Offset. 2014.

[8] Suharto F.T., Menambang Kekayaan dari Bisnis Emas Tanpa Mengeruk Alam. Jl. Palmerah Barat No. 29-32 Jakarta: Elexmedia Komputindo. 2014.

[9] Tanuwidjaja W., Cerdas Investasi Emas Tips Membeli, Menyimpan, dan Menjual Emas untuk Memperoleh Keuntungan Optimal. Jl.Irian Jaya D-24 Yogyakarta: MedPress. 2009

[10] Witten I.H., Frank E., Data Mining Practical Machine Learning Tools and Techniques. 550 Sansome Street Suite 400 San Francisco: Morgan Kaufmann. 2005.

[11] https://id.wikipedia.org/w/index.php?title=Regresi_Linear, Diakses pada tanggal 6 Oktober 2018

[12] https://cermati.com/artikel/inilah-7-produk-investasi-pilihan-beserta-kelebihan-dan-kekurangannya, Diakses pada tanggal 6 Oktober 2018

[13] https://www.investing.com/currencies/xau-usd-historical-data, Diakses pada tanggal 1 Oktober 2018 21 Februari 2019

[14] https://www.investing.com/commodities/crude-oil-historical-data, Diakses pada tanggal 1 Oktober 2018 - 21 Februari 2019

[15] https://www.investing.com/currencies/usd-idr-historical-data, Diakses pada tanggal 1 Oktober 2018 21 Februari 2019

[16] https://www.bi.go.id/id/moneter/bi-7day-RR/data/Contents/Default.aspx, Diakses pada tanggal 1 Oktober 2018 - 21 Februari 2019

[17] https://docs.rapidminer.com/latest/studio/operators/modeling/predictive/functions/linear_regression.ht ml, Diakses pada tanggal 10 Oktober 2018

[18] https://mifx.com/education-read/course-1/3/8/pengenalan-dunia-trading, Diakses pada tanggal 10 Oktober 2018

[19] https://www.finansialku.com/karat-emas-alasan-investasi-emas/, Diakses pada tanggal 10 Oktober 2018 


\section{BIBLIOGRAFI PENULIS}

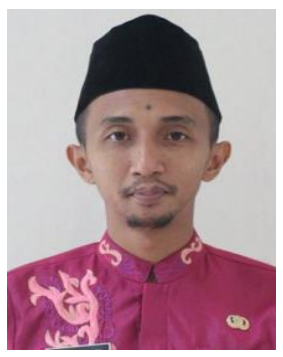

Iman Priyadi, ST, M.Kom, Sebagai Staf Sub Bagian Aplikasi Informatika dan Postel, Bagian Komunikasi dan Informatika Sekretariat Daerah Kabupaten Kepulauan Meranti

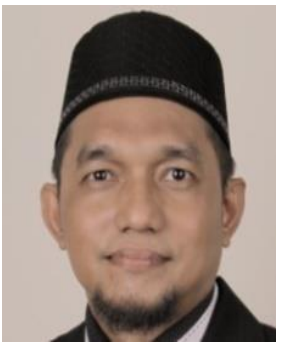

Dr. Julius Santony, S. Kom., M. Kom., currently works at the Computer Science, Universitas Putra Indonesia YPTK. Julius does research in Computing in Mathematics, Natural Science, Engineering and Medicine, Image Processing. Their current project is 'Infiltrate Object Extraction in X-ray Image by Using Math-Morphology Method and Feature Region Analysis'.

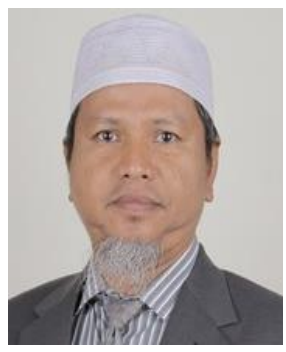

Dr. Jufriadif Na'am, S. Kom., M. Kom, dilahirkan di Padang pada Tanggal 03 Februari 1967, merupakan Dosen Universitas Putra Indonesia "YPTK" Padang bidang Ilmu Komputer 